${ }^{3}$ Hodge SE, Spence MA, Crandall BF, et al. Huntington disease: linkage analysis with age-of-onset corrections. Am J Hum Genet 1980;5:247-54.

Correspondence and requests for reprints to $\mathrm{Dr}$
M Anne Spence, Mental Retardation Research Center, Department of Psychiatry, UCLA School of Medicine, 760 Westwood Plaza, Los Angeles, California 90024, USA.

\title{
DNA linkage analysis in Von Recklinghausen neurofibromatosis
}

\begin{abstract}
B R SEIZINGER*, G ROULEAU*, A H LANE*, L J OZELIUS*, A G FARYNIARZ*, J IANNAZZI*, W HOBBS*, J C ROY*,

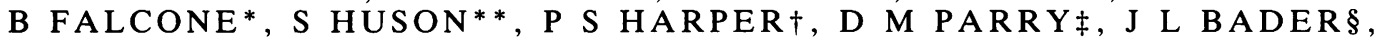
M A SPENCE\|, AND J F GUSELLA*

From *the Neurogenetics Laboratory, Massachusetts General Hospital, and Department of Genetics, Harvard Medical School, Boston, Massachusetts 02114; ${ }^{* *}$ Division of Inherited Metabolic Diseases, Clinical Research Centre, Harrow, Middlesex HA1 3UJ; †Institute of Medical Genetics, University of Wales College of Medicine, Heath Park, Cardiff CF4 4XN; ¥the Clinical Epidemiology Branch, National Cancer Institute, Bethesda, Maryland 20205; \$the Radiation Oncology Branch, National Cancer Institute, NCI-Navy Radiation Oncology Section, Bethesda, Maryland 20205; and |the Department of Psychiatry and Biomathematics, UCLA School of Medicine, Los Angeles, California 90024, USA.
\end{abstract}

SUMmARY We have used DNA linkage analysis in 11 families with Von Recklinghausen neurofibromatosis (VRNF) in order to search for the chromosomal localisation of the defective gene causing this serious neurological disorder. Three groups of polymorphic DNA markers were used: (1) markers for chromosome 22 , because of possible allelic genetic heterogeneity between VRNF and bilateral acoustic neurofibromatosis; (2) markers near the centromere of chromosome 4 , since there was preliminary evidence for linkage between the VRNF gene and Gc; and (3) oncogenes and growth factors as possible candidate genes for VRNF. Our data exclude close linkage between any of these markers and the gene for VRNF.

DNA linkage analysis was performed in 11 families with Von Recklinghausen neurofibromatosis (VRNF) according to diagnostic criteria which are in agreement with those recently established by NIH. ${ }^{1}$ Seven of these families have been described previously, ${ }^{2}$ and the other four families are among those described by Upadhyaya et al in this issue. Blood samples from 161 subjects were collected, comprising 80 samples from affected persons and 79 potentially informative meioses.

Lymphocytes were isolated from these blood samples and transformed into permanent lymphoblastoid cell lines by Epstein-Barr virus. ${ }^{3}$ DNA was isolated and digested with appropriate restriction enzymes. The resulting DNA fragments were separated according to their molecular weights by gel electrophoresis, transferred to nylon membrane, and hybridised to radiolabelled DNA probes which were known to reveal restriction fragment length polymorphisms (RFLPs) in human genomic DNA. ${ }^{3}$ DNA linkage analysis was performed by use of the linkage programme LIPED, assuming a penetrance of the defect of $95 \%$.

As shown in the table, three groups of polymorphic DNA markers were used for linkage analysis. (1) Markers for chromosome 22, since acoustic neuromas and meningiomas from patients with bilateral acoustic neurofibromatosis show highly specific deletions on this autosome, suggesting that the gene causing bilateral acoustic neurofibromatosis is located on chromosome $22 .{ }^{45}$ Furthermore, Krone and Hogemann ${ }^{6}$ reported in a recent cytogenetic study that cultured peripheral neurofibromas from patients with VRNF were associated with various chromosomal aberrations, the most consistent of which was monosomy for chromosome 22 . (2) Markers near the centromere of chromosome 4 (ALB, D4S1, and D4S35), since there was preliminary evidence for linkage between $\mathrm{Gc}$ on chromosome 4 and VRNF. ${ }^{2}$ (3) Oncogenes, growth factors, and their receptors as possible candidate genes for VRNF, a disease which is associated with tumour formation. However, the linkage data presented in the table exclude close linkage between any of these DNA markers and the gene for VRNF. 
TABLE Lod scores for linkage between DNA loci and Von Recklinghausen neurofibromatosis.

\begin{tabular}{|c|c|c|c|c|c|c|c|c|}
\hline \multirow{2}{*}{$\begin{array}{l}\text { DNA } \\
\text { marker }\end{array}$} & \multirow{2}{*}{$\begin{array}{l}\text { Chromosomal } \\
\text { localisation }\end{array}$} & \multicolumn{6}{|c|}{$\theta$ (recombination fraction) } & \\
\hline & & 0.00 & 0.05 & $0 \cdot 10$ & $0 \cdot 20$ & $0 \cdot 30$ & 0.40 & \\
\hline RAF1 & $3 \mathrm{p} 25 \rightarrow \mathrm{p} 24$ & $-\infty$ & $-5 \cdot 29$ & $-3 \cdot 18$ & -1.39 & -0.58 & -0.25 & $\bar{\omega}$ \\
\hline RAF2 & 4 pter $\rightarrow$ p 15 & $-\infty$ & -3.97 & $-2 \cdot 49$ & $-1 \cdot 08$ & -0.55 & $-0 \cdot 18$ & $\vec{D}$ \\
\hline ALB & $4 q 11 \rightarrow q 13$ & $-2 \cdot 50$ & $-1 \cdot 21$ & -0.72 & $-0 \cdot 34$ & $-0 \cdot 19$ & $-0 \cdot() 9$ & อ \\
\hline D4S1 & $4 \mathrm{p} 15 \cdot 1 \rightarrow \mathrm{q} 11$ & $-3 \cdot 70$ & $-1 \cdot 19$ & $-0 \cdot 27$ & $+0 \cdot 32$ & +0.38 & +()$\cdot 23$ & טم \\
\hline $\mathrm{ABL}$ & $9 \mathrm{p} 34$ & $-\infty$ & -0.90 & $-0 \cdot 59$ & -0.28 & $-0 \cdot 12$ & $-0 \cdot 03$ & $\rightarrow$ \\
\hline HRAS1 & $11 \mathrm{p} 15$ & $-\infty$ & $-6 \cdot 86$ & $-4 \cdot 02$ & $-1 \cdot 59$ & -0.54 & -0.25 & \\
\hline KRAS2 & $12 \mathrm{p} 12$ & $-\infty$ & $-5 \cdot 40$ & $-3 \cdot 18$ & -1.44 & $-1 \cdot 17$ & $-0 \cdot 23$ & ב \\
\hline IGF1 & $12 q 22 \rightarrow q 24 \cdot 1$ & $-\infty$ & $-2 \cdot 73$ & -1.47 & -0.47 & $-0 \cdot(04$ & $+0 \cdot 03$ & \\
\hline D22S9 & $22 \mathrm{q} 11$ & $-\infty$ & $-5 \cdot 87$ & $-3 \cdot 59$ & $-1 \cdot 52$ & -0.67 & $-0 \cdot 19$ & ర \\
\hline D22S1 & $22 \mathrm{q} 11 \cdot 2 \rightarrow \mathrm{q} 13$ & $-\infty$ & $-2 \cdot 29$ & -1.59 & $-0 \cdot 86$ & -0.42 & $-0 \cdot 15$ & 3 \\
\hline SIS & $22 \mathrm{q} 12 \cdot 3 \rightarrow \mathrm{q} 13 \cdot 1$ & $-\infty$ & -5.49 & $-3 \cdot 29$ & $-1 \cdot 33$ & -0.51 & $-0 \cdot(07$ & ح \\
\hline
\end{tabular}

We wish to thank Drs $\mathrm{R}$ White, A Ullrich, $\mathrm{R}$ Williamson, C Gilliam, T Bonner, G Bell, and D Kurnit for providing DNA probes, and K Griffin for typing the manuscript. BRS is supported by a fellowship and grant from the National Neurofibromatosis Foundation (USA) and GR by the Fonds de Recherche en Santé du Quebec and the Medical Research Council of Canada. JFG is a Searle Scholar of the Chicago Community Trust. Funds for this research were provided by NINCDS grants NS22224 and NS20012, the National Neurofibromatosis Foundation, the McKnight Foundation, the Dystonia Medical Research Foundation, and the Julieanne Dorn Fund for Neurological Research.

\section{References}

${ }^{1}$ Mulvihill J. Tentative definitions of neurofibromatosis. Neurofibromatosis Research Newsletter, 1986:2.1.
2 Spence MA, Bader J, Parry DM, et al. Linkage analysis neurofibromatosis (Von Recklinghausen disease). J Med Gen $\$ 5$ 1983;20:334-7.

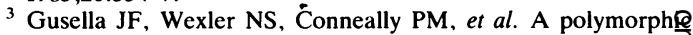
DNA marker genetically linked to Huntington's disease. Nature 1983;306:234-8.

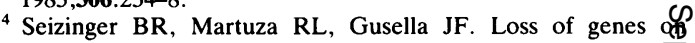
chromosome 22 in human acoustic neuroma. Nature 1986;32\% 644-7.

s Seizinger BR, Rouleau G, Ozelius LJ, et al. Common path genetic mechanism for three different tumor types in bilaterg acoustic neurofibromatosis. Science 1987;236:317-9.

6 Krone W, Hogemann I. Cell culture studies on neurofibronat $\vec{\infty}$ sis (Von Recklinghausen). V. Monosomy 22 and other chrofing somal anomalies in cultures from peripheral neurofibromas. Hum Genet 1986;74:453-5.

Correspondence and requests for reprints to $\mathrm{Dr} \overrightarrow{\mathrm{B}}$ Seizinger, Neurogenetics Laboratory, Massachuset跑 General Hospital, Boston, Massachusetts 02114 USA.

(See Note added in proof on $\mathrm{p}$ 538.)

\section{Linkage studies in peripheral neurofibromatosis}

MARGARET A PERICAK-VANCE*, LARRY H YAMAOKA*, JEFFERY M VANCE*, ARTHUR S AYLSWORTH†, GEORGE O D ROSSENWASSER , P CRAIG GASKELL JR*, MARK J ALBERTS*, WU-YEN HUNG*, CAROL HAYNES*, AND ALLEN D ROSES*

From * the Division of Neurology, Department of Medicine, and $\ddagger$ the Department of Ophthalmology, Duke. University Medical Center, Durham, North Carolina 27710; and the Department of Pediatrics, University of North Carolina, Chapel Hill, North Carolina, USA.

SUMMARY Peripheral neurofibromatosis (NF) is one of the most common major genetic disorders in man. Its chromosomal location is unknown and questions regarding such factors

Received for publication 23 March 1987. Accepted for publication 24 March 1987. as genetic heterogeneity remain unanswere $\mathcal{W}^{\mathcal{W}}$ We have ascertained and sampled several large multi-generation families for linkage studiex including one family of 66 subjects, 28 of whom were affected with NF. Recombinant DNA studies of several restriction fragment lengt 